\title{
PENGEMBANGAN INSTRUMEN TES LITERASI SAINS BERBASIS KEARIFAN LOKAL DI TRENGGALEK
}

\author{
Wilis Wisnu Murti ${ }^{1)}$, Titin Sunarti ${ }^{1)}$ \\ 1)Program Studi Pendidikan Fisika, FMIPA, Universitas Negeri Surabaya, Surabaya, Jawa Timur, Indonesia \\ Corresponding author : Wilis Wisnu Murti \\ E-mail : wilis.17030184067@mhs.unesa.ac.id
}

\author{
Diterima 23 Maret 2021, Direvisi 14 April 2021, Disetujui 14 April 2021
}

\begin{abstract}
ABSTRAK
Tujuan dari penelitian ini adalah mendeskripsikan kelayakan teoritis dan empiris dari instrumen tes literasi sains fisika yang dikembangkan dan mendeskripsikan profil kemampuan literasi sains siswa. Penelitian ini menggunakan model Research and Development (R\&D) yang langkah-langkahnya mengacu pada Sugiyono (2013). Teknik pengumpulan data pada penelitian ini yaitu dengan metode validasi yang dilakukan oleh dua dosen dari jurusan Fisika Universitas Negeri Surabaya dan metode tes yang dilakukan terhadap 50 siswa. Data yang telah terkumpul dianalisis dengan metode analisis deskriptif kuantitatif. Persentase validitas teoritis rata-rata pada ranah materi, konstruksi, dan bahasa sebesar $89,82 \%$ atau berada pada kategori sangat layak. Hasil ujicoba produk pada 50 siswa dianalisis tingkat kesukaran, daya pembeda, reliabilitas, dan validitas itemnya. Dari analisis tersebut diperoleh validitas empiris sebanyak $56,25 \%$ dari keseluruhan soal dinyatakan layak secara empiris. Instrumen tes yang telah layak kemudian digunakan untuk mendeskripsikan profil kemampuan literasi sains siswa. $2 \%$ siswa dengan kategori sangat tinggi, $8 \%$ dengan kategori tinggi, 32\% dengan kategori sedang, $8 \%$ dengan kategori rendah, dan $50 \%$ dengan kategori sangat rendah. Kemampuan literasi sains pada kompetensi menafsirkan data dan bukti secara ilmiah memiliki skor rata-rata tertinggi, sedangkan mengevaluasi dan merancang penyelidikan ilmiah memiliki skor rata-rata terendah.
\end{abstract}

Kata kunci: instrumen tes; validitas teoritis; validitas empiris; profil literasi sains.

\begin{abstract}
The purpose of this study was to describe the theoritical and empirical feasibility of physical scientific literacy test instrument which was developed and to describe the profile of student scientific literacy abilitie. This study using Research and Development (R\&D) model whose steps refer to Sugiyono (2013). Data collection techniques in this study are the validation method that done by two lecturers from the phyic department of State University of Surabaya and test method that done by 50 students. The data that has been collected were analyzed using quantitative decriptive analysis method. The percentage of average theoritical validity in the realms of material, construction, and language is $89,82 \%$ or in the very feasible category. The result of product trials on 50 students analiyzed the level of difficulty, distinguishing power, reliability, and item validity. From this analysis, it is stated that $56,25 \%$ of the total questions are empirically feasible. The appropriate test instrument is then used to describe the profile of students scientific literacy abilities. $2 \%$ of students are in very high category, $8 \%$ are in high category, $32 \%$ are in medium category, $8 \%$ ar in low category, and $50 \%$ are in very low category. The cientif literacy ability in the competence to interpret data and evidence scientifically has the highest average score, while evaluating and designing scientific investigations has the lowest average score.
\end{abstract}

Keywords: test instrument; theoritical validity; empirical validity; scientific literacy profile.

\section{PENDAHULUAN}

$\mathrm{Di}$ abad 21, sains dan teknologi berkembang dengan sangat pesat di berbagai negara sehingga manusia harus mampu menyesuaikan diri terhadap perkembangan yang ada di berbagai bidang. Salah satunya yaitu pada bidang pendidikan, karena keberhasilan dalam bidang pendidikan merupakan faktor utama yang menjadi penentu maju mundurnya suatu negara di tengah arus global. Oleh karena itu, di abad 21 ini karakteristik pembelajaran diarahkan dalam memacu siswa untuk berfikir kritis, komunikatif, kreatif dan bekerja sama (Kemendikbud, 2017). Adanya tuntutan tersebut merupakan salah satu tantangan eksternal yang mendasari dikembangkannya Kurikulum 2013. Menurut Peraturan Menteri Pendidikan dan Kebudayaan Nomor 70 Tahun 2013 karakteristik dari Kurikulum 2013 sendiri yakni mengembangkan 
sikap, pengetahuan, dan keterampilan serta menerapkannya dalam berbagai situasi di sekolah dan masyarakat (Kemendikbud, 2013). Menurut Adawiyah \& Wisudawati (2017) karakteristik tersebut dimaksudkan agar ilmu pengetahuan siswa menjadi lebih dalam dengan memanfaatkan alam dan lingkungan sebagai sumber belajarnya. Karena terjadi proses belajar siswa yang dilakukan melalui fenomena alam dan sosial, maka sama halnya dengan siswa berliterasi sains. Literasi sains yang berkaitan dengan kemampuan dalam memahami informasi, ilmu pengetahuan, dan fakta dalam kehidupan sehari-hari sangat penting untuk dibekalkan pada siswa agar lebih siap dalam menghadapi era perkembangan sains dan pemanfaatan teknologi di masa yang akan dating (Mardhiyyah et al., 2016) .Menurut Bagasta et al (2018) literasi sains setiap individu sangat perlu untuk dikembangkan mengingat peran penting penguasaan literasi untuk ikut serta menyelesaikan permasalahan dalam ekonomi dan sosial di masyarakat.

Menurut Altun-Yalçin et al (2011) Literasi sains adalah pengetahuan mengenai fakta dan konsep dasar mengenai sains serta cara kerja yang berkaitan dengan penyelidikan ilmiah. Individu yang berliterasi sains akan memiliki pemahaman mengenai hakikat keilmuan, internalisasi prinsip, teori dan konsep dasar dan mampu menggunakan proses ilmiah dalam menyelesaikan permasalahan di masyarakat (Sülün et al., 2009).

PISA (Programme for International Student Assessment) merupakan program yang melakukan penelitian mengenai kemampuan literasi membaca, matematika, dan sains siswa di berbagai negara yang tergabung (Bashooir \& Supahar, 2018).Dari hasil penelitian yang dilakukan oleh PISA pada tahun 2018, nilai literasi sains siswa Indonesia sebesar 396, dimana nilai tersebut menurun setelah sebelumnya pada penelitian PISA di tahun 2015, nilai literasi sains siswa Indonesia sebesar 403. Meskipun demikian, nilai tersebut masih tetap jauh berada di bawah skor rata-rata OECD, yakni sebesar 487 (OECD, 2019). Dari data tersebut dapat dinyatakan bahwa siswa Indonesia memiliki tingkat literasi sains yang rendah. Hal ini diperkuat dengan hasil penelitian Mardhiyyah et al (2016) pada semua aspek literasi sains, diperoleh profil kemampuan literasi sains siswa masih berada pada posisi rendah. Hasil penelitian Utama et al (2019) juga menunjukan bahwa siswa masih belum mampu berliterai sains dengan baik, hal ini dibuktikan dengan rendahnya skor yang diperoleh dalam mengerjakan soal-soal literasi sains. Hasil penelitian terebut sangat memprihatinkan, mengingat pentingnya penguasaan literasi sains bagi siswa agar mampu bertahan ditengah persaingan global (Bagasta et al., 2018).

Penyebab utama rendahnya tingkat literasi sains siswa Indonesia karena instrumen penilaian yang digunakan selama ini sebagian besar hanya untuk mengukur aspek kognitif C2 saja, belum banyak memuat soal-soal untuk mengukur level kognitif C4 sampai C6, padahal soal-soal literasi sains berada pada dimensi level kognitif tingkat tinggi tersebut (O. W. Astuti et al., 2017). Sehingga Sumaryatun et al (2016) menjelaskan perlunya dilakukan pembelajaran yang berorientasi pada penguasaan lietrasi sains siswa agar siswa terbiasa untuk mengerjakan soal-soal berbasis lietrasi sains.

Berdasarkan permasalahan diatas, maka saat ini diperlukan suatu instrumen penilaian yang mampu mengukur sekaligus meningkatkan kemampuan literasi sains siswa, yakni instrumen penilaian literasi sains dimana dalam pengembangan instrumen penilaian literasi sains ini dapat melatihkan kemampuan berfikir ilmiah siswa (Sumaryatun et al., 2016). Selain untuk meningkatkan kemampuan literasi sains siswa, instrumen penilaian literasi sains juga dapat menjadi pendorong bagi siswa agar memahami hakikat sains secara lebih dalam (W. P. Astuti et al., 2012)

Eyford (1993) menyatakan bahwa sebelum siswa belajar dalam pendidikan formal, terlebih dahulu mereka belajar di lingkungan yang dibentuk oleh kebudayaan setempat. Oleh karna itu dengan mengintegrasikan kebudayaan dalam pembelajaran akan mempermudah siswa dalam memahami konsep-konsep materi pembelajaran. Pengintegrasian budaya dalam pembelajaran ini bisa dilakukan dengan mengintegrasikan kearifan lokal dalam instrumen penilaian.

Kearifan lokal adalah suatu pandangan dan pengetahuan tradisional yang turuntemurun digunakan sebagai acuan hidup bermasyarakat dalam menyelesaikan suatu permasalahan (Mardotilah et al., 2016). Kearifan lokal yang memuat permasalahan lingkungan maupun isu budaya lokal dapat dimanfaatkan sebagai sumber pembelajaran literasi sains (Perkasa, 2018). Musrotin (2019) juga menyatakan bahwa Instrumen tes terintegrasi kearifan lokal dapat menghubungkan materi fisika dengan kearifan lokal sehingga memungkinkan peserta didik untuk lebih mudah memahami aplikasi konsep fisika dalam kehidupan sehari-hari.

Karifan lokal yang diintegrasikan pada penelitian ini adalah kearifan lokal di Trenggalek. Karena di Trenggalek terdapat banyak kearifan lokal yang memungkinkan untuk dianalisis konsep fisikanya, salah satunya 
yaitu kearifan lokal larung sembonyo yang ditunjukan oleh Gambar 1.

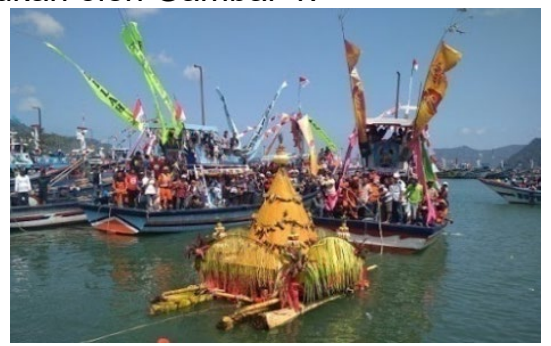

Gambar 1. Larung Sembonyo

(Sumber :Josstv.com(2018))

Kearifan lokal larung sembonyo yang dilakukan dengan melarungkan sembonyo di laut berhubungan erat dengan konsep fluida, sehingga dapat dikaji konsep fisika fluida statis dengan materi Hukum Archimedes dan konsep massa jenis. Kemudian dari kearifan lokal ritual sinongkelan dapat dianalisis konsep fisika pada materi suhu dan kalor. Karena pada prosesi sinongkelan akan berlangsung proses pembakaran seperti yang ditunjukan oleh Gambar 2.

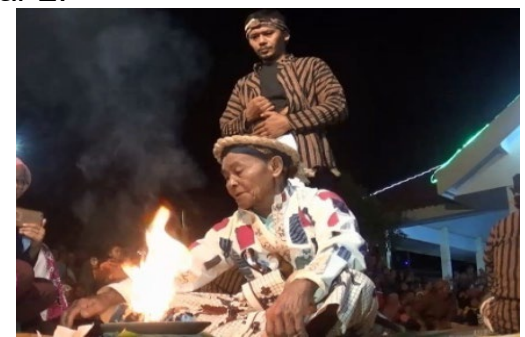

Gambar 2. Ritual Sinongkelan (Sumber : KimSumberrejeki.blogspot.com (2017))

Selanjutnya yakni kearifan lokal Nyadran dam bagong yang ditunjukan oleh Gambar 3 berikut.

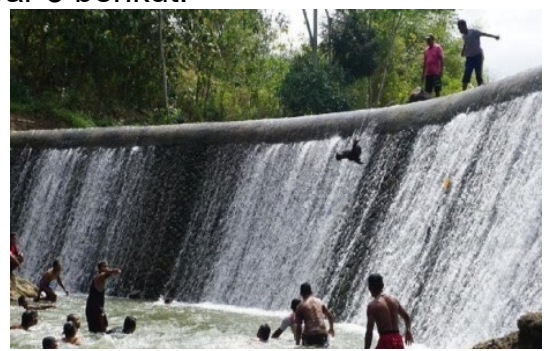

Gambar 3. Nyadran Dam Bagong (Sumber : newsdetik.com(2018))

Kearifan lokal Nyadran dam bagong dilakukan dengan melemparkan sesaji dari atas sungai yang akan ditangkap dan diperebutkan oleh warga yang telah masuk ke dalam sungai. Karena sesaji dilempar ke bawah dengan kecepatan awal tertentu dan membentuk sudut tertentu terhadap sumbu $\mathrm{x}$ horizontal dan sumbu y vertikal sehingga dapat dikembangkan soal pada materi gerak parabola.

Kemudian pada upacara Jemasan pusaka akan dilakukan jemasan (memandikan) pusaka, dimana salah satu pusaka yang dijemas pada upacara tersebut yaitu tombak korowelang yang ditunjukan oleh gambar 4 .

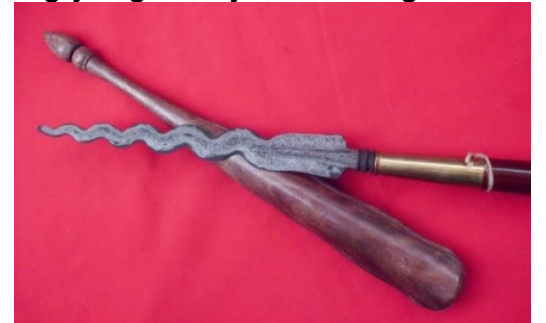

Gambar 4. Pusaka pada Ritual Jemasan (Sumber : Budayanuswantara.blogspot.com (2014))

Dari pusaka tombak korowelang tersebut dapat dikaji konsep fisika fluida statis pada materi tekanan. Kemudian juga dapat dikembangkan soal pada materi suhu dan kalor pada proses pembuatan keris yang juga dijemas pada upacara jemasan pusaka itu sendiri.

Sebelumnya telah banyak dilakukan penelitian terkait Pengembangan Instrumen Penilaian Literasi Sains yang diantaranya dilakukan oleh Mardhiyyah et al (2016), dan Novanti et al (2018). Namun penelitian yang akan di lakukan ini memiliki kelebihan yakni instrumen penilaian yang dikembangkan berbasis kearifan lokal di Trenggalek.

Berdasarkan uraian di atas, maka akan dilakukan penelitian dengan tujuan mendeskripsikan kelayakan teoritis dan empiris dari instrumen tes literasi sains fisika berbasis kearifan lokal yang telah dikembangkan serta mendeskripsikan profil kemampuan literasi sains siswa. Produk yang dikembangkan yaitu instrumen tes literasi sains berbasis kearifan lokal di Trenggalek.

\section{METODE PENELITIAN}

Penelitian ini menggunakan model Penelitian dan Pengembangan (Research and Development) dengan produk yang dikembangkan adalah instrumen tes literasi sains fisika berbasis kearifan lokal di Trenggalek. Adapun prosedur yang digunakan dalam penelitian ini adalah mengikuti model penelitian dan pengembangan yang diadaptasi dari Sugiyono (2013). dengan langkah-langkah pengembangannya yakni 1. Analisis potensi dan masalah; 2. Pengumpulan data; 3. Desain produk; 4. Validasi; 5. Revisi desain; 6. Draft final; 7. Ujicoba produk; 8. Analisis; 9. Laporan. Teknik pengumpulan data yaitu dengan metode validasi yang dilakukan oleh dua dosen dari jurusan Fisika Universitas Negeri Surabaya dan metode tes yang dilakukan terhadap 50 siswa. Data yang telah terkumpul dianalisis dengan metode analisis deskriptif kuantitatif. 
Dari analisis potensi dan masalah, dikembangkan 16 butir soal tes berbentuk uraian yang mencakup tiga kompetensi literasi sains. Untuk mendeskripsikan kelayakan secara teoritis terhadap perangkat tes yang dikembangkan, maka dilakukan validasi pada ranah materi, konstruksi, dan bahasa oleh dua dosen dari jurusan fisika Universitas Negeri Surabaya. Pengumpulan data pada tahap validasi ini menggunakan lembar validasi. Untuk menghitung persentase validitas pada setiap indikator digunakan rumus sebagai berikut.

$$
\text { validitas }=\frac{\text { Skor yang diperoleh }}{\text { Skor maksimum }} \times 100 \%
$$

Dengan kriteria dari persentase validitas dinyatakan oleh Tabel 1.

Tabel 1. Kriteria Kategori Validitas Teoritis Instrumen Tes

\begin{tabular}{cc}
\hline Persentase (\%) & Kriteria \\
\hline $0-20$ & Sangat lemah \\
\hline $21-40$ & Lemah \\
\hline $41-60$ & Cukup \\
\hline $61-80$ & Layak \\
\hline $81-100$ & Sangat Layak \\
\hline
\end{tabular}

(Riduwan, 2012)

Setelah dinyatakan valid secara teoritis, kemudian dilakukan ujicoba produk terhadap 50 siswa dari kelas XI di SMA Negeri 1 Durenan Trenggalek untuk mendeskripsikan kelayakan empiris yang meliputi tingkat kesukaran, daya pembeda, reliabilitas, dan validitas item dari instrumen tes yang dikembangkan. Adapun tingkat kesukaran soal dianalisis menggunakan rumus sebagai berikut.

$$
\text { Tingkat kesukaran }=\frac{\frac{\sum X}{N}}{\text { skor maksimum }}
$$
Keterangan

$\sum X \quad$ : Jumlah skor siswa tiap butir soal $\mathrm{N} \quad$ : Jumlah siswa

Kategori kriteria tingkat kesukaran setiap butir soal dinyatakan oleh Tabel 2.

Tabel 2. Kriteria Kategori Tingkat Kesukaran

$$
\text { Butir Soal }
$$

\begin{tabular}{cc}
\hline Nilai Tingkat Kesukaran & Kriteria \\
\hline $0,00-0,30$ & Sukar \\
\hline $0,30-0,70$ & Sedang \\
\hline $0,71-1,00$ & Mudah \\
\hline
\end{tabular}

$$
\text { (Arifin, 2013) }
$$

Selanjutnya daya pembeda item soal dihitung menggunakan rumus berikut.

Keterangan

$$
\text { Daya pembeda }=\frac{\bar{X} K_{A}-\bar{X} K_{B}}{\text { Skor maksimum }}
$$

$\bar{X} K_{A} \quad$ : Rata-rata kelompok atas

$\bar{X} K_{B} \quad$ : Rata-rata kelompok bawah

Kategori kriteria daya pembeda item soal dinyatakan oleh Tabel 3 berikut.
Tabel 3. Kriteria Kategori Daya Pembeda

\begin{tabular}{cc}
\hline Nilai Daya Pembeda & Kriteria \\
\hline$\geq 0,40$ & Sangat baik \\
\hline $0,30-039$ & Baik \\
\hline $0,20-0,29$ & Cukup \\
\hline$\leq 0,19$ & Rendah \\
\hline
\end{tabular}

(Arikunto, 2012)

Selanjutnya yaitu analisis reliabilitas. Untuk jenis soal uraian, perhitungan reliabilitasnya menggunakan rumus Alpha sebagai berikut.

$$
r_{11}=\left(\frac{n}{n-1}\right)\left(1-\frac{\sum \sigma_{i}^{2}}{\sigma_{t}^{2}}\right)
$$

Keterangan

$r_{11}$ : Koefisien reliabilitas yang dicari

$\mathrm{n}:$ Jumlah item tes

$\sum \sigma_{i}^{2}:$ Jumlah varians skor tiap-tiap item

$\sigma_{t}^{2}$ : Varians soal

Kemudian $r_{11}$ dibandingkan dengan $r$ product moment. Instrumen tes dinyatakan reliabel jika $r_{11}$ lebih besar dari $r$ product moment (Arikunto, S., 2012). Untuk validitas item dihitung menggunakan rumus berikut.

$$
r_{x y}=\frac{N \sum X Y-\left(\sum X\right)\left(\sum Y\right)}{\sqrt{\left(N \sum X^{2}-\left(\sum X\right)^{2}\left(N \sum Y^{2}-\left(\sum Y\right)^{2}\right)\right.}}
$$

Keterangan:

$r_{x y}:$ validitas butir tes

$X$ : skor tes pada butir soal

$Y$ : skor total yang dicapai

$\mathrm{N}$ : jumlah siswa

Kategori kriteria validitas item dinyatakan pada Tabel 4 berikut.

Tabel 4. Kriteria Kategori Validitas Item Soal

\begin{tabular}{cc}
\hline Nilai $\mathbf{r}_{\mathbf{x y}}$ & Kriteria \\
\hline $0,81<r \leq 1,00$ & Sangat tinggi \\
\hline $0,61<r \leq 0,80$ & Tinggi \\
\hline $0,41<r \leq 0,60$ & Cukup \\
\hline $0,21<r \leq 0,40$ & Rendah \\
\hline $0,00<r \leq 0,20$ & Sangat rendah \\
\hline \multicolumn{2}{c}{ (Arifin, 2013) } \\
Butir soal yang telah valid secara
\end{tabular}
empiris kemudian digunakan untuk mendeskripsikan profil kemampuan literasi sains siswa. Analisis profil kemampuan literasi sains siswa untuk masing-masing kompetensi literasi sains menggunakan rumus sebagai berikut.

$$
\text { nilai siswa }=\frac{\text { skor jawaban benar }}{\text { skor maksimum }} \times 100 \%
$$

Kategori profil kemampuan literasi sains siswa dapat dilihat pada Tabel 5.

Tabel 5. Kriteria Kategori Profil Kemampuan Literasi Sains Siswa

\begin{tabular}{cc}
\hline Interval (\%) & Kategori \\
\hline $86-100$ & Sangat tinggi \\
\hline $76-85$ & Tinggi \\
\hline
\end{tabular}




\begin{tabular}{cc}
\hline $60-75$ & Sedang \\
\hline $55-59$ & Rendah \\
\hline$\leq 54$ & Sangat rendah \\
\hline
\end{tabular}

(Rahmadani et al., 2018)

\section{HASIL DAN PEMBAHASAN}

Pada tahap pertama, yakni analisis potensi dan masalah. Masalah yang melatar belakangi dilakukannya penelitian ini dikarenakan dari hasil penelitian PISA, kemampuan literasi peserta didik Indonesia masih sangat rendah dan selalu mengalami penurunan peringkat (OECD, 2019). Kemudian ditinjau dari beberapa jurnal diantaranya jurnal penelitian dari Mardhiyyah et al (2016) dan Utama et al (2019) yang menyatakan bahwa profil literasi sains peserta didik di Indonesia masih rendah.

Selanjutnya dari studi pendahuluan diperoleh informasi bahwa di SMAN 1 Durenan Trenggalek telah menerapkan Kurikulum 2013, sehingga dalam proses pembelajarannya seharusnya telah mengarah pada pembelajaran yang berorientasi literasi sains. Selanjutnya, pada tahap desain produk dilakukan pembentukan instrumen tes literasi sains. Dimulai dengan pembentukan kisi-kisi sebelum membuat soal. Dimana soal yang disusun sebanyak 16 butir berbentuk uraian yang terintegrasi kearifan lokal, diantaranya 4 butir soal dari kompetensi menjelaskan fenomena ilmiah, 5 butir soal dari kompetensi menafsirkan data dan bukti secara ilmiah, dan 7 soal dari kompetensi mengevaluasi dan merancang penyelidikan ilmiah. Dari kearifan lokal Ritual sinongkelan dikaji konsep fisika pada materi suhu dan kalor yakni pada proses pembakaran dupa tongan yang akan mendatangkan angin. Contoh soal dari kompetensi menjelaskan fenomena ilmiah yang digali dari fenomena tersebut terdapat pada butir soal nomor 1 sebagai berikut.

"Setelah dilakukan pembakaran terhadap dupa tongan, akan ada angin bertiup menuju ke tempat upacara. Jika dianalisis secara ilmiah mengapa hal tersebutdapat terjadi ?"

Dari kearifan lokal Nyadran dam bagong dikaji konsep fisika pada materi gerak parabola. yakni pada proses pelemparan sesaji yang lintasannya berbentuk parabola. Salah satu contoh soal literasi sains dari kompetensi menafsirkan data dan bukti secara ilmiah yang digali dari fenomena tersebut terdapat pada butir soal nomor 7 yakni sebagai berikut.

"Agar dapat menangkap sesaji dengan tepat, pada jarak berapakah pak Andi sebaiknya berdiri ? $\left(\mathrm{g}=10 \mathrm{~m} / \mathrm{s}^{2}\right) "$

Dari kearifan lokal Larung sembonyo diambil fenomena pada proses pelarungannya, yakni bahan rakit sembonyo yang memungkinkan sembonyo untuk mengapung pada saat dilarungkan. Dari fenomena tersebut disusun suatu teks bacaan untuk menggali kemampuan literasi sains siswa pada kompetensi mengevaluasi dan merancang penyelidikan ilmiah terkait pengaruh bentuk bahan terhadap nilai massa jenisnya. Untuk contoh pertanyaan literasi sainsnya dapat dilihat pada butir soal nomor 3 sebagai berikut. "Tentukan pertanyaan ilmiah yang dapat dijadikan sebagai rumusan masalah dari percobaan yang akan dilakukan !"

Instrumen tes yang telah disusun kemudian divalidasi ranah materi, konstruksi, dan bahasanya oleh dua dosen validator dari jurusan fisika Universitas Negeri Surabaya. Dari validasi tersebut, diperoleh revisi berupa perbaikan rumusan soal, kalimat-kalimat dalam teks bacaan dan indikator item soal yang kemudian diberikan penilaian untuk dianalisis validitas teoritisnya.

Indikator penilaian pada ranah materi yang dinilai oleh validator yaitu:

1. Soal sesuai indikator

2. Kalimat soal menginformasikan dengan jelas mengenai batasan jawaban yang harus dijawab

3. Soal sesuai dengan tujuan

Rata-rata hasil penilaian validator dalam persentase untuk masing-masing indikator pada ranah materi disajikan oleh diagram pada Gambar 5 berikut.

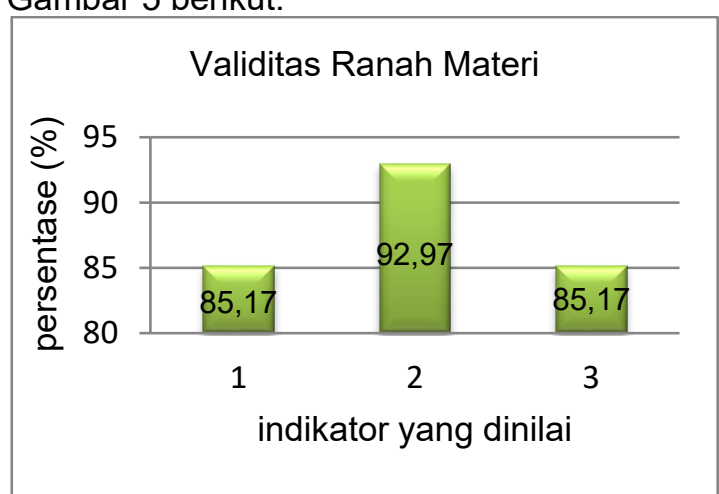

Gambar 5. Diagram Persentase Validitas pada Ranah Materi

Dari keseluruhan indikator yang dinilai pada ranah materi diperoleh persentase ratarata sebesar $87,77 \%$ dengan kriteria sangat layak.

Indikator penilaian pada ranah konstruksi yang dinilai oleh validator yaitu:

1. Rumusan kalimat bacaan dan soal menggunakan kata tanya atau perintah yang menuntut

2. Terdapat pedoman penskoran

3. Gambar, tabel, grafik, diagram dan sejenisnya disajikan dengan jelas dan terbaca 
Rata-rata hasil penilaian validator dalam persentase untuk masing-masing indikator pada ranah konstruksi disajikan oleh diagram pada Gambar 6 berikut.

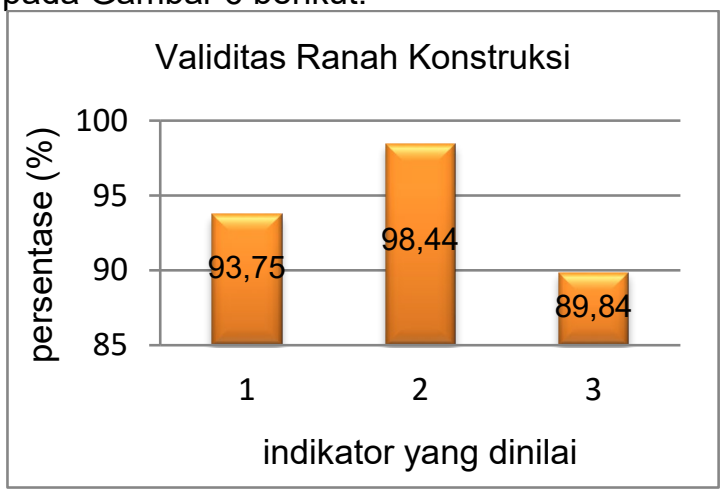

Gambar 6. Diagram Persentase Validitas pada Ranah Konstruksi

Dari keseluruhan indikator yang dinilai pada ranah konstruksi diperoleh persentase rata-rata sebesar $94,01 \%$ dengan kriteria sangat layak.

Selanjutnya indikator penilaian pada ranah bahasa yang dinilai oleh validator yaitu:

1. Rumusan kalimat soal komunikatif

2. Butir soal menggunakan bahasa yang baik dan benar

3. Rumusan soal tidak menggunakan kata/kalimat yang menimbulkan penafsiran ganda atau salah pengertian

4. Rumusan soal tidak mengandung kata-kata yang dapat menyinggung

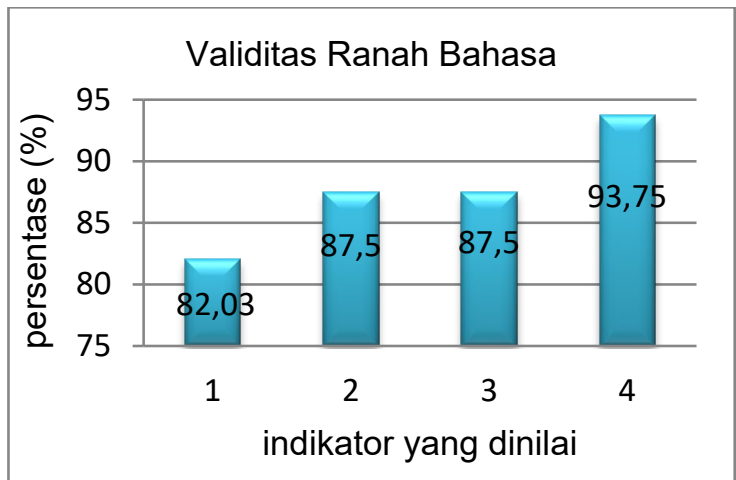

Gambar 7. Diagram Persentase Validitas Ranah Bahasa

Rata-rata hasil penilaian validator dalam persentase untuk masing-masing indikator pada ranah konstruksi disajikan oleh diagram pada Gambar 7. Dari keseluruhan aspek yang dinilai pada ranah bahasa diperoleh persentase rata-rata sebesar $87,70 \%$ dengan kriteria sangat layak.

Menurut Riduwan (2012) instrumen tes dinyatakan valid secara teoritis apabila memiliki persentase kelayakan $\geq 61 \%$. Dengan demikian, instrumen tes yang telah dikembangkan dapat dinyatakan layak, karena dari keseluruhan hasil penilaian validator pada ranah materi, konstruksi, dan bahasa memiliki persentase kelayakan rata-rata sebesar $89,82 \%$ atau berada pada kategori sangat layak. Draft final yang telah layak secara teoritis tersebut selanjutnya diujicobakan kepada siswa.

Dari hasil ujicoba kepada siswa, dapat dianalisis validitas empiris dari instrumen tes yang dikembangkan yang meliputi tingkat kesukaran soal, daya pembeda, reliabilitas, dan validitas item. Untuk persentase tingkat kesukaran soal disajikan oleh diagram pada Gambar 8 berikut.

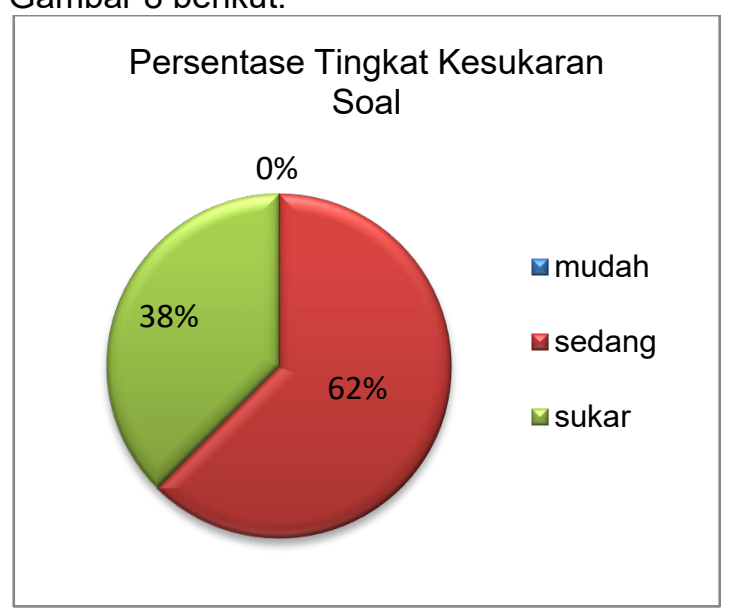

Gambar 8. Diagram Persentase Tingkat Kesukaran Soal

Dari Gambar 8 dapat dilihat bahwa dari 16 butir soal tes literasi sains yang dikembangkan, sebanyak $62 \%$ berada pada kategori sedang. Menurut Sudijono (2009) butir-butir item tes dapat dinyatakan menjadi butir-butir item tes yang baik apabila memiliki tingkat kesukaran yang tidak terlalu sukar namun juga tidak terlalu mudah (sedang). Kemudian terdapat $38 \%$ soal berada kategori sukar, dan tidak terdapat soal yang berada pada kategori mudah. Soal yang terlalu mudah tidak akan memacu perkembangan peserta didik terkait upaya pemecahannya, sedangkan soal yang terlalu sulit akan membuat peserta didik putus asa dan tidak semangat dalam mencari penyelesaian soal yang dihadapi (Arikunto, 2012).

Selanjutnya persentase daya pembeda dari soal yang dikembangkan disajikan oleh diagram pada Gambar 9 berikut. 


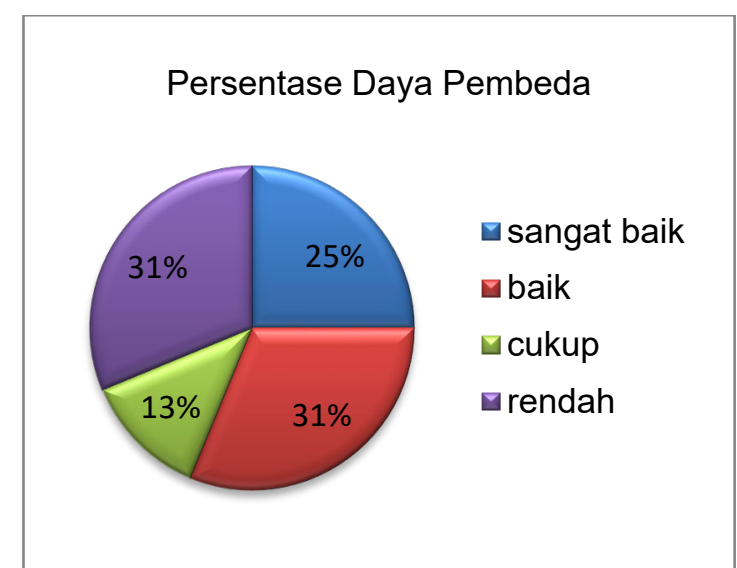

Gambar 9. Diagram Persentase Daya Pembeda

Dari Gambar 9 dapat dilihat bahwa dari 16 butir soal yang dikembangkan, sebanyak $25 \%$ memiliki daya pembeda dengan kriteria sangat baik, $31 \%$ dengan kriteria baik, 13\% berada pada kriteria cukup. Menurut Adawiyah \& wisudawati (2017) soal yang memiliki daya pembeda berkriteria baik memiliki kemampuan yang baik untuk membedakan antara siswa yang telah memahami kompetensi dengan yang belum memahami. Kemudian terdapat $31 \%$ dari 16 soal yang memiliki kategori kurang baik. Soal dengan daya pembeda yang kurang baik tidak mampu membedakan siswa yang telah memahami kompetensi dengan yang belum memahami. Dimana pada soal yang memiliki daya pembeda tidak baik, hasil pengerjaan soal antara siswa yang berada di kelompok atas dan siswa di kelompok bawah akan memberikan skor yang sama-sama tinggi atau sama-sama rendah (Indrawati \& Sunarti, 2018).

Instrumen tes dikatakan reliabel bukan berarti nilai tes harus sama persis pada setiap pengukuran, melainkan tes harus mampu menunjukan persamaan kedudukan peserta didik di antara anggota kelompok yang lain (Arikunto, 2012). Reliabilitas dihitung menggunakan rumus Alpha dan selanjutnya dikonsultasikan dengan tabel r produk moment. Instrumen yang telah dikembangkan ini memiliki nilai $r$ hitung sebesar 0,87 . Nilai tersebut kemudian dibandingakan dengan $r$ tabel taraf signifikansi $5 \%$ untuk $\mathrm{N}=50$, yang mana diperoleh nilai $r$ tabel sebesar 0,28. Dalam sugiyono (2013) dikatakan bahwa instrumen tes dinyatakan reliabel jika nilai $r$ hitung lebih besar dari $r$ tabel. Instrumen yang telah dikembangkan memiliki nilai $r$ hitung= 0,87 yang lebih besar dari nilai $r$ tabel $=0,28$, sehingga dapat disimpulkan bahwa instrumen yang telah dikembangkan dinyatakan reliabel.

Melalui perhitungan menggunakan teknik korelasi product moment dengan angka kasar diperoleh nilai validitas item setiap butir soal. Persentase validitas item butir soal berdasarkan kriterianya direpresentasikan oleh diagram pada Gambar 10 di bawah ini.

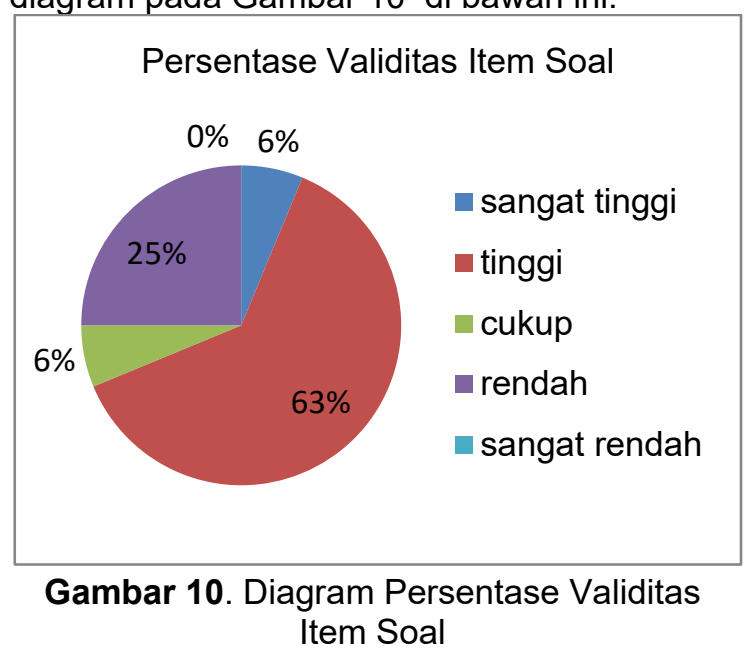

Dari Gambar 10 dapat dilihat bahwa sebanyak $6 \%$ dari 16 soal yang telah dikembangkan memiliki validitas item dengan kategori sangat tinggi, kemudian $63 \%$ berada pada kategori tinggi, $6 \%$ berada pada kategori cukup, dan $25 \%$ berada pada kategori rendah dan tidak ada soal yang memiliki validitas item sangat rendah. Butir soal yang memiliki validitas item rendah menurut Arikunto (2009) tidak valid karena skor item butir soal tidak mendukung skor total, dimana skor yang diperoleh siswa pada item-item tersebut adalah seragam (hampir sama) padahal skor total yang diperoleh berbeda-beda atau antar siswa memiliki rentang skor total yang besar.

Berdasarkan analisis tingkat kesukaran, daya pembeda, dan validitas item, diperoleh $56,25 \%$ dari 16 soal yang dinyatakan valid secara empiris. Jadi, terdapat 9 butir soal yang dinyatakan valid secara empiris. Butir soal tersebut yaitu soal nomor 1, 2, dan 11 dengan kompetensi literasi sains menjelaskan fenomena ilmiah, kemudian nomor 3, 5, dan 6 dengan kompetensi merancang penyelidikan ilmiah, dan butir soal nomor 13, 14, 15 dengan kompetensi menafsirkan data dan bukti secara ilmiah. Butir soal yang telah valid secara empiris maupun teoritis tersebut kemudian digunakan untuk mengidentifikasi profil literasi sains siswa pada kelas ujicoba. Dimana hasilnya disajikan oleh diagram pada Gambar 11 berikut ini. 


\section{Persentase Kemampuan Literasi} Sains Siswa Secara Umum

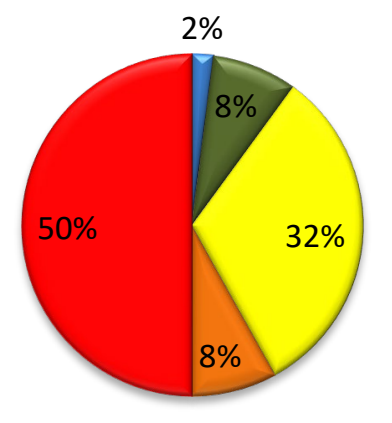

sangat tinggi rtinggi

$\square$ sedang

$\square$ rendah
Gambar 11. Diagram persentase kemampuan literasi sains siswa

Pada Gambar 11 dapat dilihat bahwa kemampuan literasi sains $50 \%$ siswa berada pada kategori sangat rendah dan $8 \%$ berada pada kategori rendah. Hal ini menunjukan bahwa mayoritas siswa belum memiliki kemampuan literasi sains yang baik. Sebenarnya, sekolah telah menerapkan Kurikulum 2013 yang seharusnya dalam proses pembelajarannya sudah mengarah pada pembelajaran yang berorientasi literasi sains. Meskipun demikian, proses penilaian yang dilakukan belum mengacu pada peningkatan pemahaman literasi sains siswa. siswa belum banyak dilatih untuk mengerjakan soal-soal berbasis literasi sains. Menurut Kurnia et al (2014) terdapat banyak faktor yang mempengaruhi rendahnya kemampuan literasi sains siswa, salah satunya yaitu metode dan model pembelajaran yang digunakan oleh guru dalam menyampaikan materi kepada siswa. Oleh karena itu guru harus cermat dalam menentukan metode dan model pembelajaran yang tepat agar kemampuan literasi sains siswa meningkat.

Akan tetapi, dari keseluruhan siswa terdapat $2 \%$ siswa yang memiliki kemampuan literasi sains sangat tinggi dan $8 \%$ berada pada kategori tinggi. Hal tersebut dikarenakan kelas yang digunakan dalm ujicoba terdiri dari siswa yang memiliki kemampuan kognitif heterogen. Sehingga siswa yang memiliki kemampuan kognitif tinggi mampu untuk mengerjakan soal literasi sains yang diberikan meskipun mereka belum terbiasa mengerjakan soal berbasis literasi sains sebelum-sebelumnya. Pernyataan ini didukung oleh Rosidah \& Sunarti (2017) yang mana dinyatakan bahwa siswa yang memiliki kemampuan tingkat kognitif tinggi akan mampu untuk menalar dan berfikir kritis yang lebih tinggi dalam menyelesaikan suatu permasalahan.

Selanjutnya, untuk kemampuan ratarata literasi sains siswa pada masing-masing kompetensi literasi sains dapat dilihat pada diagram di Gambar 12 berikut.

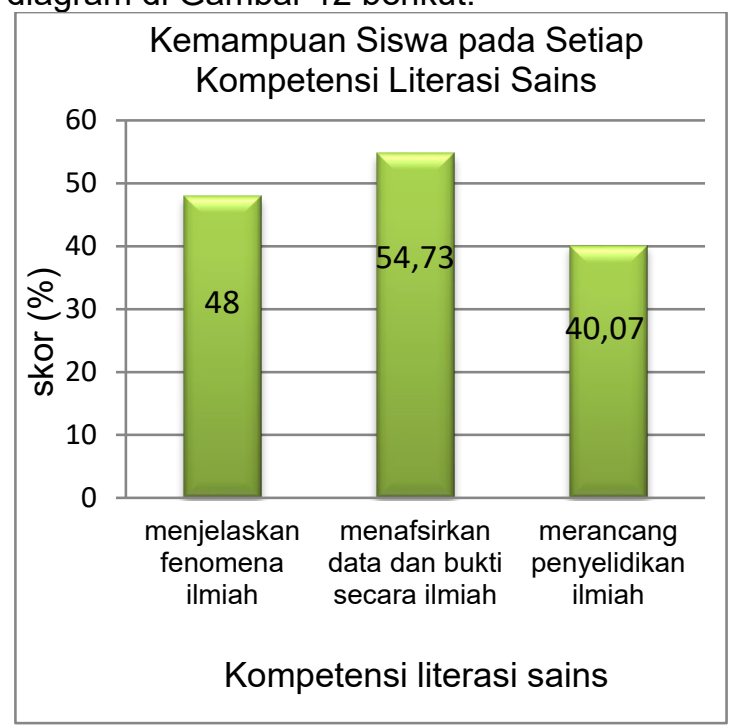

Gambar 12. Diagram Kemampuan Siswa pada Masing-Masing Kompetensi Literasi Sains

Dari Gambar 12 dapat dilihat skor perolehan rata-rata pada masing-masing kompetensi literasi sains. Kompetensi menafsirkan data dan bukti secara ilmiah memiliki skor tertinggi sebesar $54,73 \%$ meskipun berada pada kategori rendah. Hal ini menunjukan bahwa dari ketiga kompetensi lietrasi sains, menafsirkan data dan bukti secara ilmiah merupakan kompetensi yang paling dikuasai oleh siswa. Dari analisis jawaban pengerjaan soal oleh siswa, rata-rata siswa sudah mampu untuk menggambar grafik meskipun belum cukup sempurna, mampu menganalisis grafik yang telah dibuat meskipun belum didukung oleh teori yang matang, dan mampu membuktikan hasil prediksinya terhadap suatu permasalahan dengan menerapkan konsep fisika yang dikuasai. Contohnya, siswa mampu memprediksi jenis logam yang digunakan dan membuktikan kebenarannya dengan melakukan perhitungan untuk menemukan nilai koefisien muai volume berdasarkan data hasil percobaan yang disajikan.

Kemudian kompetensi menjelaskan fenomena ilmiah memiliki kategori skor yang sangat rendah yakni sebesar $48 \%$. Hal tersebut terjadi karena siswa belum terbiasa dalam memahami konsep seacara utuh dan menyeluruh atau hanya sekedar menghafal rumus dan menerapakan rumus untuk menyelesaikan soal. Pernyataan tersebut didukung oleh Utama et al (2019) yang menyatakan bahwa rendahnya kemampuan siswa dalam kompetensi menjelaskan fenomena ilmiah dikarenakan siswa hanya memahami konsep-konsep materi secara 
hafalan. Dalam pembelajaran di kelas, guru kurang mengajak siswa untuk menganalisis permasalahan-permasalahan di sekitar yang memungkinkan untuk dianalisis konsep ilmiahnya. Mendukung pernyataan tersebut, Angraini (2014) menyatakan bahwa rendahnya kemampuan literasi sains pada kompetensi menjelaskan fenomena ilmiah disebabkan karena proses pembelajaran yang dilakukan di kelas kurang mengajak siswa untuk menganalisis penyebab dari suatu fenomena suains di lingkungan sekitar

Selanjutnya skor terendah diperoleh pada kompetensi merancang penyelidikan ilmiah dengan skor sebesar $40,07 \%$. Dari analisis jawaban, rata-rata siswa belum mampu dalam menjelaskan prosedur yang akan digunakan pada suatu percobaan. Rata-rata siswa menganggap bahwa pada percobaan massa jenis, ketika menimbang bahan, gelas ukur juga ikut ditimbang. Kemudian terdapat beberapa siswa yang juga beranggapan bahwa untuk menentukan nilai massa jenis hanya dengan mencelupkan bahan ke dalam gelas ukur yang berisi air lalu menghitung selisih volume sebelum dicelupkan bahan kedalamnya dengan volume setelah dicelupkan bahan ke dalamnya. Sebagian besar siswa juga belum memahami hipotesis percobaan. Pada butir soal yang meminta untuk menentukan hipotesis dari percobaan yang akan dilakukan, beberapa siswa justru menjelaskan teori dari massa jenis itu sendiri dan menganggap bahwa jawaban yang berupa teori tersebut merupakan hipotesis. Rendahnya skor yang diperoleh pada kompetensi merancang penyelidikan ilmiah ini menurut Sumaryatun et al (2016) dikarenakan kurangnya inisiatif guru dalam melakukan pembelajaran berbasis praktikum. Sehingga siswa cenderung tidak memahami prosedur ilmiah dalam melakukan praktikum. Jika memungkinkan dilakukannya praktikum, hanya sebatas melakukan percobaan dengan mengaitkan konsep, tidak sampai pada tahap analisis maupun penyusunan laporan dengan benar. Mardhiyyah et al (2016) juga menyatakan bahwa pendidikan di Indonesia lebih menekankan abstract conceptualization, sedangkan pada active experimentation kurang dikembangkan. padahal active experimentation ini memungkinkan siswa untuk mengadakan percobaan sendiri untuk menemukan jawaban atas persoalan-persoalan yang dihadapi.

\section{SIMPULAN DAN SARAN Simpulan}

Dari analisis data hasil validasi diperoleh validitas teoritis dari instrumen tes literasi sains berbasis kearifan lokal yang dikembangkan berada pada kategori sangat layak, baik pada ranah materi, konstruksi, maupun bahasa, dengan persentase rataratanya sebesar $89,82 \%$. Kemudian dari hasil uji validitas empiris yang meliputi tingkat kesukaran soal, daya pembeda, reliabilitas, dan validitas item, diperoleh $56,25 \%$ atau sebanyak 9 dari 16 butir soal dinyatakan layak secara empiris. Butir soal yang telah layak kemudian digunakan untuk mengidentifikasi profil kemampuan literasi sains siswa, dimana sebanyak $2 \%$ berada pada kategori sangat tinggi, $8 \%$ berada pada kategori tinggi, $32 \%$ berada pada kategori sedang, $8 \%$ berada pada kategori rendah, dan $50 \%$ berada pada kategori sangat rendah. Untuk kemampuan literasi sains pada masing-masing kompetensi literasi sains, menafsirkan data dan bukti secara ilmiah memiliki persentase skor rata-rata tertinggi yakni $54,73 \%$, kemudian menjelaskan fenomena ilmiah sebesar $48 \%$ sedangkan mengevaluasi dan merancang penyelidikan ilmiah memiliki persentase skor rata-rata terendah yakni $40,07 \%$.

\section{Saran}

Guru disarankan untuk menggunakan instrumen literasi sains yang dikembangkan untuk melatih siswa dalam meningkatkan kemampuan literasi sains. Pengembangan soal lietrasi sains pada materi lain sebaiknya juga dilakukan.

\section{UCAPAN TERIMAKASIH}

Diucapkan terimakasih kepada dosen pembimbing yang telah memberikan bimbingan mulai dari penyusunan instrumen penelitian sampai penyelesaian artikel dan Kepada guru Fisika di SMAN 1 Durenan Trenggalek yang telah membantu saya dalam proses pengambilan data, serta semua pihak yang telah membantu saya sehingga saya dapat menyelesaikan artikel ini.

\section{DAFTAR RUJUKAN}

Adawiyah, R., \& Wisudawati, A. W. (2017). Pengembangan Instrumen Tes Berbasis Literasi Sains: Menilai Pemahaman Fenomena IImiah Mengenai Energi. Indonesian Journal of Curriculum, 5(2), 112-121.

Altun-Yalçin, S., Açşli, S., \& Turgut, Ü. (2011). Determining the levels of pre-service science teachers' scientific literacy and investigating effectuality of the education faculties about developing scientific literacy. Procedia - Social and Behavioral Sciences, 15, 783-787. https://doi.org/10.1016/j.sbspro.2011.03.1 85 
Angraini, G. (2014). Analisis Kemampuan Literasi Sains Siswa SMA Kelas X di Kota Solok. Prosiding Mathematics and Sciences Forum, 161-170.

Arifin, Z. (2013). Evaluasi Pembelajaran. Bandung: PT Remaja Rosdakarya.

Arikunto, S. (2009). Dasar-Dasar Evaluasi Pendidikan (Edisi revisi). Jakarta: Bumi Aksara.

Arikunto, S. (2012). Dasar-Dasar Evaluasi Pendidikan (2nd ed.). Jakarta: Bumi Aksara.

Astuti, O. W., Zulyusri, \& Putri, D. H. (2017). Pengembangan Instrumen Asesmen Berbasis Literasi Sains pada Mata Pelajaran IPA Kelas VIII Semester II ( Development of the Scientific Literacy Assessment Based on Science Subjects Class VIII Semester II ). Journal Biosains, 1(2), 227-234.

Astuti, W. P., Prasetyo, A. P. B., \& Rahayu, E. S. (2012). Pengembangan Instrumen Asesmen Autentik Berbasis Literasi Sains Pada Materi Sistem Ekskresi. Lembaran IImu Kependidikan, 41(1).

Bagasta, A. R., Rahmawati, D., M., D. M. F. Y., Wahyuni, I. P., \& Prayitno, B. A. (2018). Profil Kemampuan Literasi Sains Peserta Didik di Salah Satu SMA Negeri Kota Sragen. PEDAGOGIA: Jurnal Pendidikan, $7(2)$, 121. https://doi.org/10.21070/pedagogia.v7i2.1 551

Bashooir, K., \& Supahar. (2018). Validitas dan reliabilitas instrumen asesmen kinerja literasi sains pelajaran Fisika berbasis STEM. Jurnal Penelitian Dan Evaluasi Pendidikan, 22(2), 168-181. https://doi.org/10.21831/pep.v22i2.20270

Budayanuswantara.blogspot.com. (2014). Tombak Legenda Korowelang. Retrieved from

http://budayanuswantara.blogspot.com/2 014/02/tombak-legenda-korowelang.html

Eyford, H. (1993). Relevant Education: the Cultural Dimensions. Papua New Guinea Journal of Education, 29, 9-19.

Indrawati, M. D., \& Sunarti, T. (2018). Pengembangan Instrumen Penilaian Literasi Sains Fisika Peserta Didik Pada Bahasan Gelombang Bunyi Di Sma Negeri 1 Gedangan Sidoarjo. Jurnal Inovasi Pendidikan Fisika (JIPF), 07(01), 14-20.

Josstv.com. (2018). Upacara Adat Labuh Laut Larung sembonyo Trenggalek. Retrieved from https://josstv.com/2018/08/08/979/

Kemendikbud. (2013). Peraturan Menteri Pendidikan dan Kebudayaan Republik Indonesia Nomor 70 Tahun 2013 tentang
Kerangka Dasar dan Struktur Kurikulum Sekolah Menengah Atas/Madrasah Aliyah. Jakarta

Kemendikbud. (2017). Konsep Literasi Sains dalam Kurikulum 2013. Jakarta: Pusat Kurikulum dan Perbukuan.

Kim-sumberrejeki.com. (2017). Tradisi Ritual Unik "Grebeg Sinongkel" Bersih Desa Prambon Trenggalek. Retrieved from https://kim-

sumberrejeki.blogspot.com/2017/09/tradi si-ritual-unik-grebeg-sinongkel.html

Kurnia, F., . Z., \& Fathurohman, A. (2014). Analisis Bahan Ajar Fisika Sma Kelas Xi Di Kecamatan Indralaya Utara Berdasarkan Kategori Literasi Sains. Jurnal Inovasi Dan Pembelajaran Fisika, 1(1), 43-47. https://doi.org/10.36706/jipf.v1i1.1263

Mardhiyyah, L. A., Rusilowati, A., \& Linuwih, S. (2016). Pengembangan Instrumen Asesmen Literasi Sains Tema Energi. Journal of Primary Education, 5(2), 147154.

Mardotilah, F., Sardianto, Pasaribu, A., \& Saparini. (2016). Efektivitas Pembelajaran Fisika Menggunakan Lembar Kerja Siswa ( Lks ) Fisika Berbasis Kearifan. Jipf, 116124.

Musrotin. (2019). Pengembangan Instrumen Tes Berbasis Literasi Saintifik Terintegrsi Kearifan Lokal pada Materi Kalor di SMP/MTs. Universitas Islam Negeri Walisongo.

Newsdetik.com. (2018). Hormati Waduk Desa, Petani Trenggalek Larung Kepala Kerbau. Retrieved from https://news.detik.com/berita-jawatimur/d-4148773/hormati-waduk-desapetani-trenggalek-larung-kepala-kerbau

Novanti E. K. S., Yulianti E., M. R. V. (2018). Pengembangan Instrumen Tes Literasi Sains Siswa Smp Materi Tekanan Zat Dan Penerapannya Dalam Kehidupan SehariHari. Jurnal Pembelajaran Sains, 2(2009), 6-12.

OECD. (2019). PISA 2018 Assesment and Analytical Framework. Paris: OECD Publishing.

Perkasa, M. (2018). Bahan Ajar Berorientasi Environmental Sustainability Education Berintegrasi Kearifan Lokal Untuk Meningkatkan Literasi Sains Mahasiswa. Lentera Pendidikan : Jurnal IImu Tarbiyah Dan Keguruan, 21(2), 246. https://doi.org/10.24252/lp.2018v21n2i10

Rahmadani, Y., Fitakurahmah, N., Fungky, N., Prihatin, R., Majid, Q., \& Prayitno, B. A. (2018). Profil Keterampilan Literasi Sains Siswa di Salah Satu Sekolah Swasta di 
Karanganyar. Jurnal Pendidikan Biologi, $7(3)$,

183.

https://doi.org/10.24114/jpb.v7i3.10123

Riduwan. (2012). Skala Pengukuran VariabelVariabel Penelitian. Bandung: Alfabeta.

Rosidah, F. E., \& Sunarti, T. (2017). Pengembangan Tes Literasi Sains Pada Materi Kalor Di Sma Negeri 5 Surabaya. Inovasi Pendidikan Fisika, 6(3), 250-257.

Sudijono, A. (2009). Pengantar Evaluasi Pendidikan. Jakarta: Raja Grafindo Persada.

Sugiyono. (2013). Metode Penelitian Kuantitatif, Kualitatif, dan R\&D. Bandung: Alfabeta.

Sülün, Y., Yurttas, G. D., \& Ekiz, S. O. (2009). Determination of science literacy levels of the classroom teachers (A case of Muğla city in Turkey). Procedia - Social and Behavioral Sciences, 1(1), 723-730. https://doi.org/10.1016/j.sbspro.2009.01.1 27

Sumaryatun, Rusilowati, A., \& Nugroho, S. E. (2016). Pengembangan Instrumen Penilaian Autentik Kurikulum 2013 Berbasis Literasi Sains Pada Materi Bioteknologi. Journal of Primary Education, 5(1), 66-73.

Utama, M. N., Ramadhani, R., Rohmani, S. N., \& Prayitno, B. A. (2019). Profil Keterampilan Literasi Sains Siswa Di Salah Satu Sekolah Menengah Atas (Sma ) Negeri Di Surakarta Students ' Science Literacy Skill Profile in One of State High Schools in Surakarta. 3, 57-67. 